\title{
Study of histopathological changes by Staphylococcus aureus in kidney and ability to produce B-Lactamase
}

\author{
Reem Zuhair Shinshal \\ Education College for girls/University of Mosul
}

Received

26/7/2006
Accepted

4/9/2006

\section{الخلصة}

صممت الدرلسة للتعرف على مدى قابلية المكورات العقودية على لحداث الاص ابة

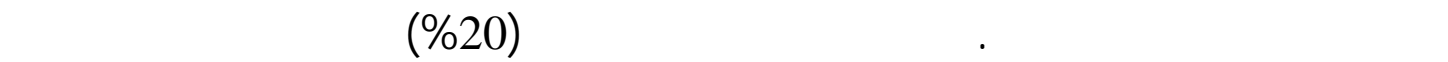
المقطع النسيجية المرضية للكلية ارتشاح خلايا التهابية في النسج الخلالي وفي قثرة وم تن

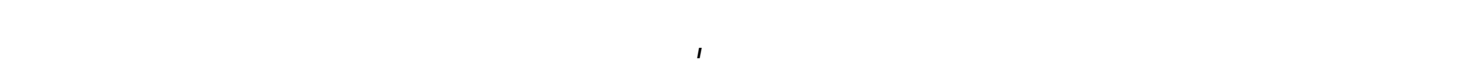

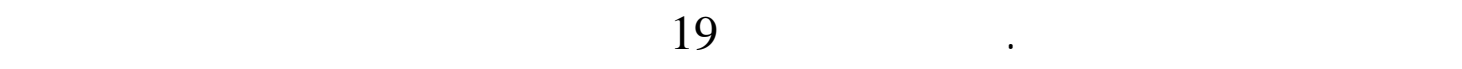
وبنسبة (64\%)و6سلالات كانتسالبة وبنسبة(36\%).

\section{Abstract}

The study performed to explain the extreme susceptibility of the mouse kidney to the infection with Staphylococcus aureus by intraperitoneal inoculation. The percentage of the infection is (20\%), histopathological examination showed many changes such as infiltration of the Inflammatory cells in interstitial tissue,cortex and medulla of the kidney, and around the blood vessels, glomerulitis, addition to heamorrhage, necrosis in the cortex and medulla of the kidney. 19 Strains were positive for B-Lactamase production test (64\%) and 6 were negative (36\%)

\section{Introduction}

The bacterial infections are very important for both males and females of different ages worldwide (1). Gram positive, cocci are the main cause of morbidity and mortality in the renal unit setting (2). These organisms cause many diseases such as septicaemia, pneumonia , endocarditis , osteomyelitis , gastroenteritis and cystitis , nephritis, pyelonephritis, acute urethral syndrome and pyuria in women $(1,3)$.

The infection of urinary tract by staphylococcus aureus leads to immunodeficiency, immune dysfunction in addition to decrease in 
complement activity and immunocytes $(4,5,6)$. Retarding in diagnosis and treatment of pathological cases leads to uplift morbidity (7).

The phenomenon of tolerance of $S$. aureus to bactericidal activity of drugs has been described in recent years. In general , B-Lactam antibiotics have been bactericidal for $S$. aureus at concentrations equal to or close to those required for inhibition. In tolerant strains, however , considerably more antibiotic is needed.

B-Lactam antimicrobial agent such as penicillins and cephalosporins are often used to treat the infection and inhibit bacteria by interfering with cell-wall synthesis $(8,9,10)$.

Specifically , B-Lactam antimicrobial agents inhibit the transpeptidase enzymes that are essential for peptidoglycan synthesis in bacteria (10).

B-Lactamase is a type of enzyme produced by some bacteria, this enzyme is responsible for their resistance to B-Lactam antibiotics like penicillins, cephalosporins (11).

In the present study we applied a method of intraperitoneal infection in mice with Staphylococcus aureus to study the mechanism of staphylococcal infection in mice specially histopathologically and to test the production of B-Lactamase against the antibiotics.

\section{Materials and Methods}

\section{A- The samples}

(25) Strains of staphylococcus aureus from patients (males and females of different ages) suffering from pain of kidney, in Al-Zahrawii Hospital, from July to November. 2005, inoculated on brain heart infusion agar, brain heart infusion broth, incubated in $37^{\circ} \mathrm{C}$ for $24 \mathrm{hr}$. and then stored in a refrigerator up to use.

\section{B- Experimental animals}

(25) adult mice from breed BALB/C of both sexes, distributed randomly in five groups, five mice in each group , $2.7 * 10^{7} \mathrm{cfu} / \mathrm{g}$ $(0.5 \mathrm{ml})$ of bacterial solution inoculated intraperitoneally for each mice (12), animals were killed after (10) days, specimens of kidney were taken and fixed in (10\%) buffered formalin solution for histological examination.

\section{C- Histological examination}

Histological sections were prepared and stained by Eosine and haematoxylin (13).

\section{D- B- Lactamase production test}

(25) Strains were tested for B- Lactamase production, 2 Bibulous papers were used, each paper was put in a sterile petri dish, first paper is control, second paper is under test, $(0.02 \mathrm{mg})$ of penicillin $\mathrm{G}$ was put in the center of each paper, $0.08 \mathrm{ml}$ of distilled water was added, part of 
bacterial colony was transferred by a loop to the second paper, spreaded in the paper center and mixed with penicillin $G$, then stored at room temperature for (10) minutes, to each paper (3-5) drops of Logol's iodine were added, appearance of a white color through (5) minutes indicates a positive response (14).

\section{Results and Discussion}

The results of this study showed an infiltration of inflammatory cells in interstitial tissue, cortex and medulla of the kidney (picture 1) and around the blood vesseles (picture 2), this agreed with $(15,16,17,18)$.

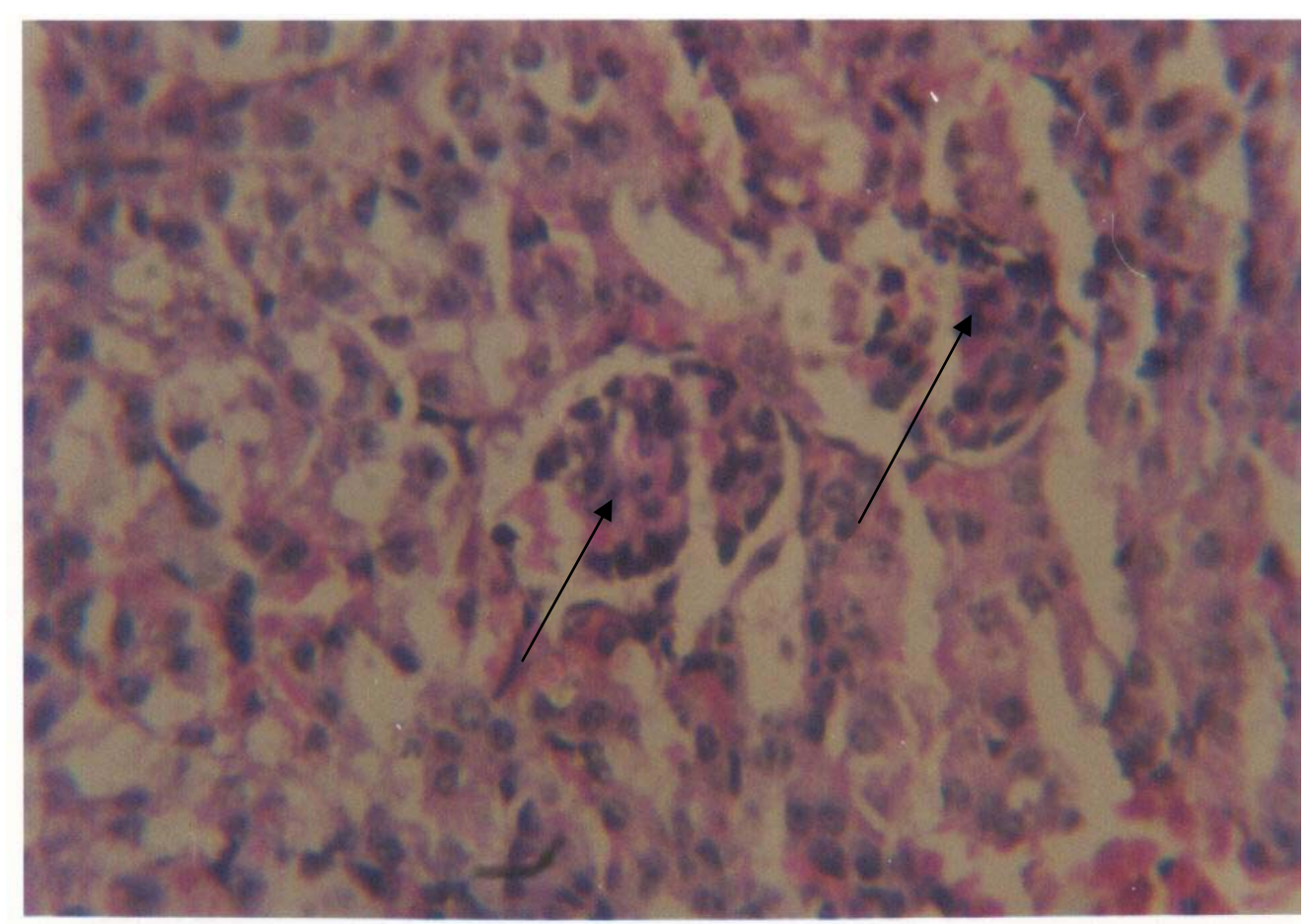

Picture (1) : Infiltration of inflammatory cells in interstitial tissue, cortex and medulla of the kidney 


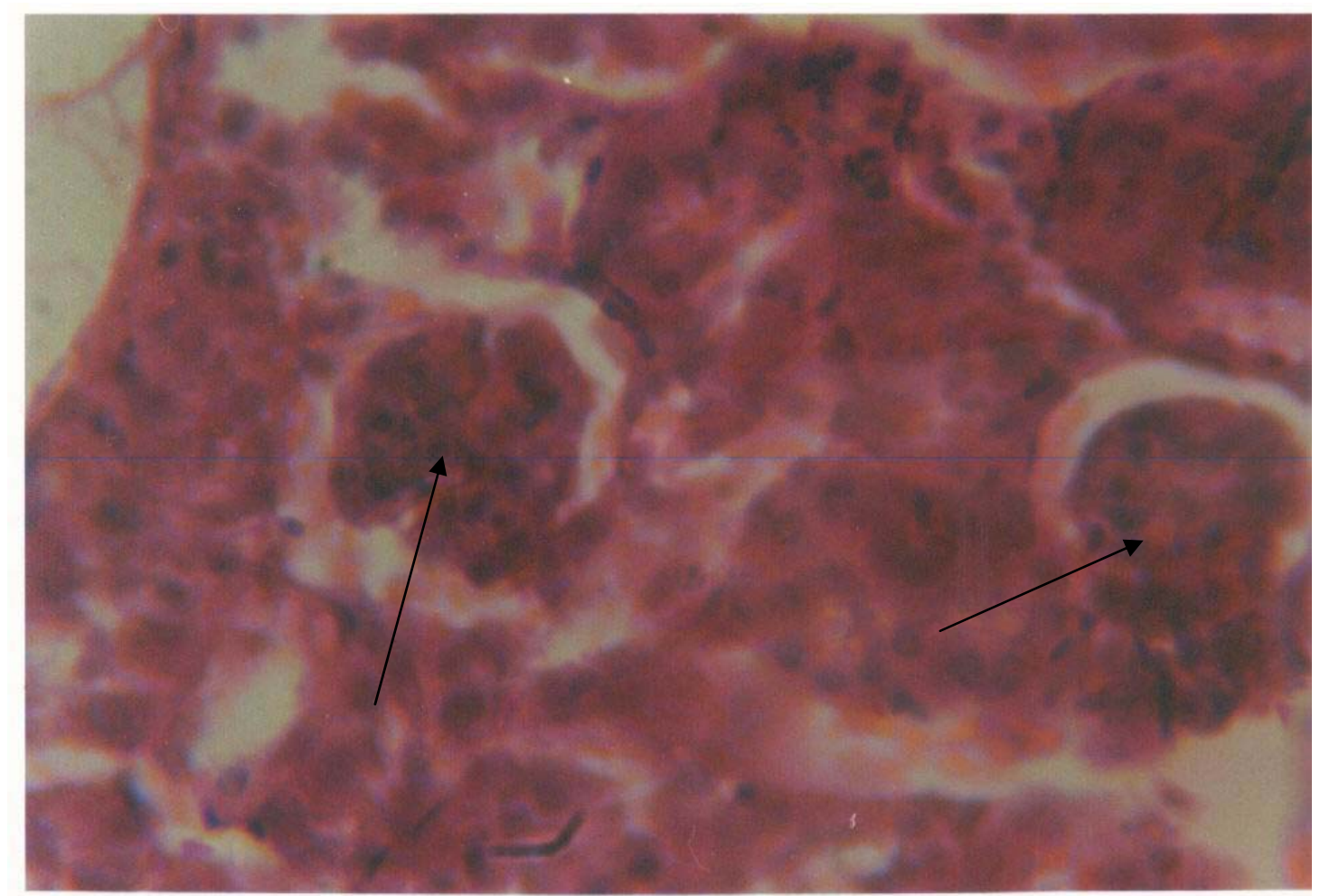

\section{Picture (2) : Infiltration of inflammatory cells around the blood vesseles}

Other study showed that experimental pyelonephritis was induced by intravenous inoculation of $S$. aureus in Wister rats.

The route of inoculation differs from the present study but the results are the same because both of them are belonging to virulence of the organism (19), another study showed the absence of immunoglobin suggesting that the toxic action of $S$. aureus antigens may activate complement and cause glomerular injury and that immune complexes are not essential for the production of glomerulonephritis in this entry (20).

The results of the present study showed heamorrhage near the renal pelvic and the cortex (picture 3), this result agreed with $(15,21)$, glomerulitis in the cortex and necrosis in the renal tubules with heamorrhage between these tubules in the cortex (picture 4), these results are in agreement with $(21,22)$ but not in agreement with (23), this may be due to the bacterial species, strains and virulence. 


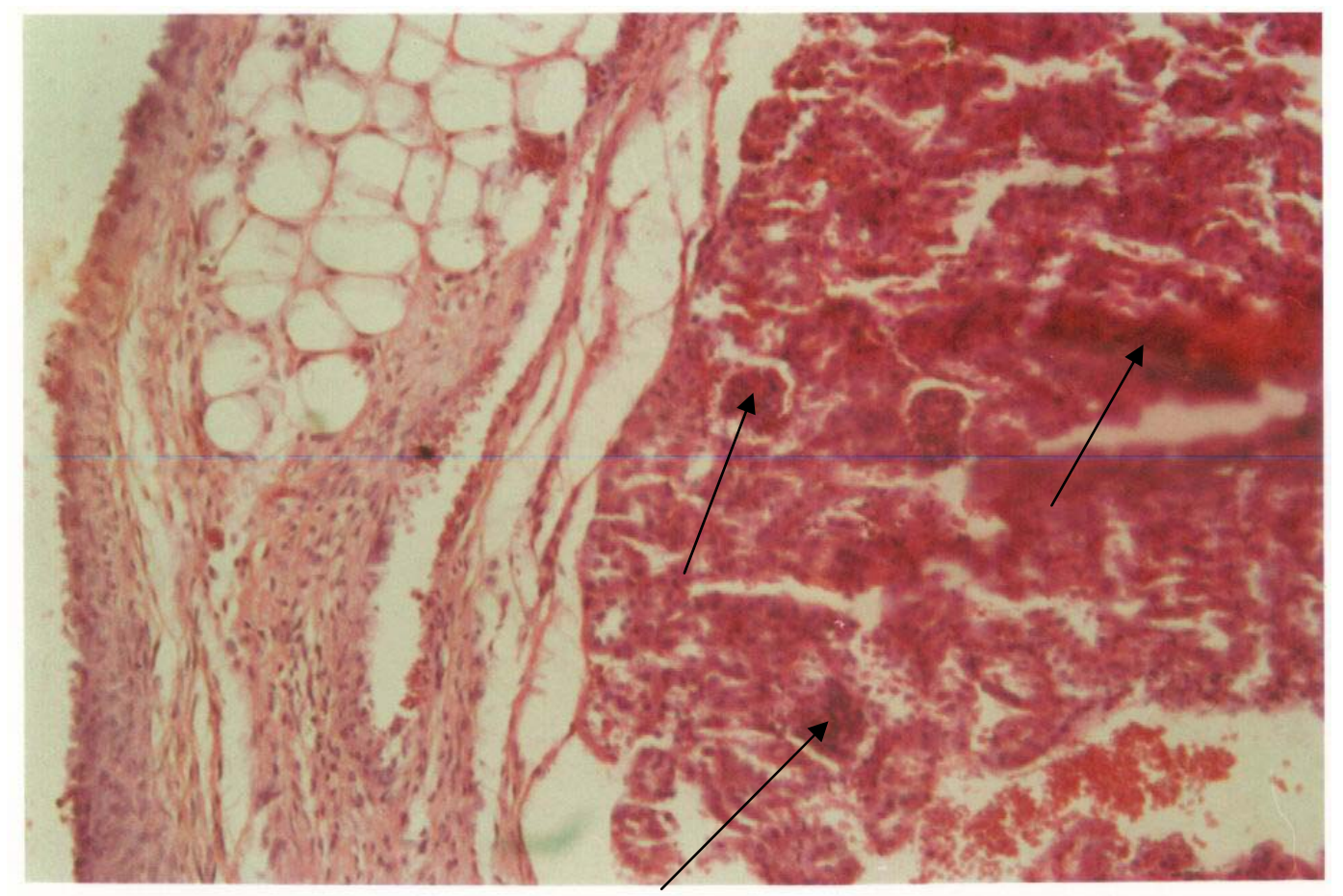

Picture (3) : Heamorrhage near the renal pelvic and the cortex

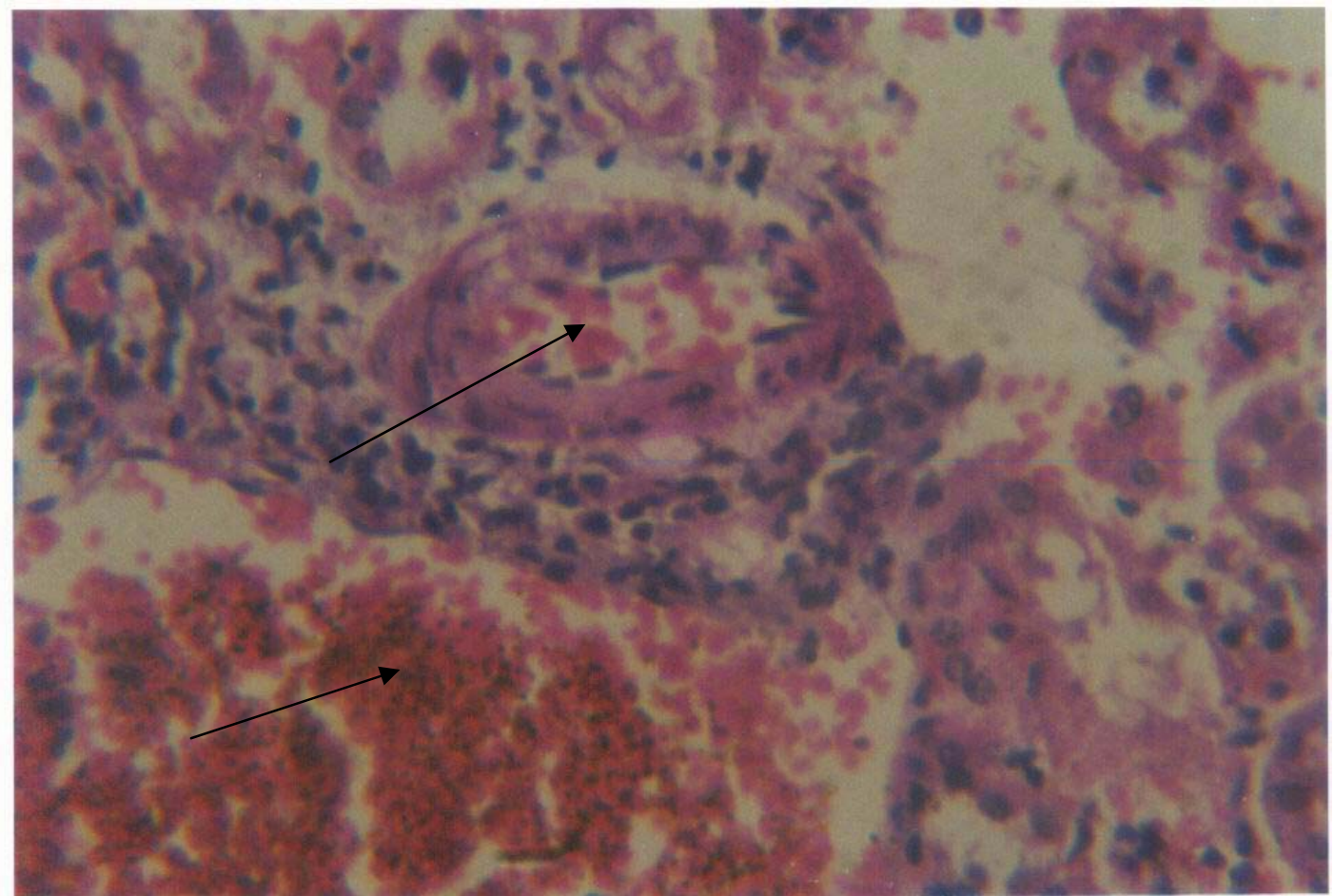

Picture (4) : glomerulitis in the cortex and necrosis in the renal tubules with heamorrhage between these tubules in the cortex 
Penicillins, cephalosporins have a common element in their molecular structure : A four - atom ring known as B-Lactam, the Lactamase enzyme breaks that ring open, deactivating the molecules and antibacterial properties (11) penicillinase is a particular type of BLactamase with molecular weight of about 50.000, showing specificity for penicillins by hydrolysing the B-Lactam ring, also penicillinase was the first B-Lactamase to emerge, due to the early dependence on penicillin, penicillinase resistant B-Lactamase was then developed such as methicillin although there is widespread resistance against them (24).

The production test of B-Lactamase commercially prepared by easy and quick, method expressed data about resistance of $S$. aureus to the antibiotics penicillin G and cephalosporin (14). From (25) strains of S. aureus , 19 strains (64\%) showed positive B-Lactamase production suggesting the existence of multiresistant strains , 6 strains (36 \%) were B-Lactamase negative. In this study two compounds demonstrated effective activity against $S$. aureus strains that were both positive and negative for B-Lactamase, these results agreed with $(25,26)$.

\section{References}

1- Finegold M. and Martin , J. (1982), Diagnostic microbiology, $6^{\text {th }}$ edition, the c.v. Mosby company, St. Louis. Toronto. London.

2- Peacock , S. J., Mandal, S. and Bowler, I.C. J.W. (2002). Preventing staphylococcus aureus infection in the renal unit Q. J. Med, 95 : 405-410.

3- Jawetz, Jo, Hoiby, N. (1998). Coagulase - negative staphylococcus in a major Danish university hospital diversity in antibiotic susceptibility between wards, Ampis, $106: 411-416$.

4- $\quad$ Raska, K. Jr, Raskova, J., Shea, SM, Frankel RM, Wood RH, Lifter J, Ghobrial I, Eisinger RP, Homer L. (1983). T cell subsets and cellular immunity in end-stage renal disease, Am J. Med; 75 : 734 40.

5- $\quad$ Fujigaki , Y. Yousif , Y. Morioka, T. Batsford, S. Vogt A., Hishida A., Miyasaka M., (1998). Glomerular injury induced by cationic $70-$ $\mathrm{KD}$ staphylococcal protein, specific immune response is not involved in early phase in rats J. pathol. , Apr. ; 184 (4): 436 - 45.

6- Yokota, N., Morita H., Iwasaki S., Ooba H., Ideura T. Yoshimura A., (2001). Reversible nephrotic syndrome in a patient with amyloid 
A amyloidosis of the kidney following methicillin resistant staphylococcus aureus infection, Nephron, Feb; 87 (2) : 177 - 81.

7- $\quad$ Sanae Sasaki, Shinsuke Nishikawa , Tomisato Miura , Mayuko Mizuki, Kyogo Yamada, Hiroo Madaramae, Yoh - Ichi Nakane, (2000) Interleukin - 4 and interleukin - 10 are involved in host resistance to staphylococcus aureus infection through regulation of gamma interferon , Infection and Immunity Vol. 68 , No. 5, p. 2424 2430.

8- Eliopoulis, G.M. (1986). Penicillins page 144 in the antimicrobial agents annual 1.P.K. Peterson and J. Verhoof, ed. Elsevier Sci, publ., New York, NY.

9- $\quad$ Sanders, C.C. and W.E. Sanders, Jr., (1986). The cephalosporins and cephamycins. Page 66 in the antimicrobial agents annual 1. P.K. Paterson and J. Verhoof, ed. Elsevier Sci. Publ. , New York, NY.

10- Yao, J.D.C., and R.C. Moellering , Jr. , (1995). Antibacterial agents. Page 1281 in Manual of clinical microbiology $6^{\text {th }}$ ed. P.R . Murray, E.J. Baron, M.A. pfaller , F.C. Tenover , and R.H. Yolken, ed. Am., Soc. Microbial , Washington, DC.

11- Rossi S. (2004). Australian medicines handbook Adelaide : Australian medicines handbook. ISBN O 9578521 - 4- 2 .

12- Sultan (2001). Diagnostic and pathological study of staphylococcus aureus that negative to coagulase test isolated from urinary tract infection in female for age of mature in Mosul city, M.Sc. thesis Coll. Sci. Univ. Mosul.

13- Luna, L.G. (1968). Manual of histologic staining of the armed forces institute of pathology. $3^{\text {rd }}$ ed. McGraw-Hill Comp. U.S.A.

14- Lee W.S. and Komary, L. (1982). Idometric spot test for detection of B-Lactamase in Haemophilus influenzae , J. Clin. Microbial, 13(1): $224-255$.

15- Isamu Kondo, Shogo Masuda , Kozo Kimura, Kosei Kurosaka and Noriko Hasegawa, (1971). Effects of intrarenal inoculation of staphylococcus aureus on mice, Infection and Immunity. Aug, p. $103-109$.

16- Stewart I.E., Borland C. (1994). Case report. Perinephric - splenic fistula - a complication of the perinephric abscess drainage $\mathrm{Br}$. J. Radiol, Sep.; 67 (801) : $894-6$.

17- Verba, V., Sakiniene E., Tarkowski A. (1997). Beneficial effect of glucocorticoids on the course of haematogenously acquired staphylococcus aureus. Nephritis scand J. Immunol Mar., 45(3) : $282-6$.

18- Hoeven - Arentzen, P.H. Van and Apeldoom, M.E. Van (1997). Pesticide residues in food, sponsored jointly by FAO and WHO with the support of the international program on chemical safety (IPCS). 
19- Koyuncuoglu H., Gungor M., Mng O., Inanc D., Ang-Kucuker M., Sagduyu H, Uysal V., (1988). Aggravation by morphine and D-aspartic acid of pyelonephritis induced by I.V. inoculation of staphylococcus aureus in rats. Infection 16 (1): $42-5$.

20- Pertschuk Lp, Woda BA. , Vuletin JC., Brigati DJ, Soriano CB, Nicastri AD (1976). Glomerulonephritis due to staphylococcus aureus antigen, Am. J. Clin. Pathol. Mar; 65 (3) : 301 - 7.

21- Teelucksingh S., Ariyanayagam DC, Fung K.F., (1994). Perinephric abscess mimicking fulminal failure - west - Indian Med., J., Jun.; 43 (2) : 66 - 7.

22- Alifano M., Venissac N, Chevallier D, (1999). Nephrobronchial fistula secondary to xantograntous pyelonephritis. Ann. Thorac surg Nov. ; 68 (5) : 1836 - 7.

23- Botkina E.M. Kutchak SN, Stebaeva LF, Shipilova LD. (1981). Structural changes in renal tissue in experimental staphylococcal Septicopyemia, Antibiotiki , Aug; 26 (8) : 623 - 8.

24- Jacoby GA, Munoz-price LS. (2005). The new B-Lactamases , N. Engl. J. Med. ; 352 : 380 - 91.

25- Watls J.L. and Salmon S.A. (1997). Activity of selected antimicrobial agent aginst strains of staphylococcus aureus isolated from bovine intramammary infections that produce B-Lactamase, J. Dairy Sci , $80: 788$ - 791.

26- Bernardo, W.L., Carvalho, Boriollo, Marcelo F. G. , Goncalves, Reginaldo B. and Hofling J.F. (2005). Staphylococcus aureus ampicillin - resistant from the odontological clinic environment Rev. Inst. Med. Trop. S. paulo 47 (1) : 19 - 24 Jan - Feb. 